\title{
RELATIONSHIP BETWEEN TRAINING VOLUME AND BONE MINERAL DENSITY CHANGES IN ELDERLY WOMEN
}

\author{
RELAÇÃO ENTRE O VOLUME DE TREINAMENTO E MUDANÇAS DE DENSIDADE MINERAL ÓSSEA \\ EM MULHERES IDOSAS
}

Artigo Original

Original ARticLe

Artículo Original

\begin{abstract}
RELACIÓN ENTRE VOLUMEN DE ENTRENAMIENTO Y CAMBIOS EN LA DENSIDAD MINERAL ÓSEA EN MUJERES MAYORES
\end{abstract}

\author{
Juan José Rábade Espinosa' \\ (Educador Físico) \\ Teresa Valverde Esteve \\ (Educadora Física) \\ Ana Pablos Monzó \\ (Educadora Física) \\ Carlos Pablos Abella' \\ (Educador Físico) \\ Vicente Carratalá Deval ${ }^{1}$ \\ (Educador Físico) \\ 1. Institute of Sciences of Physical \\ Activity and Sport, Catholic \\ University of Valencia, Spain.

\section{Correspondence:} \\ Institute of Sciences of Physical \\ Activity and Sport, Catholic \\ University of Valencia, Spain. \\ Ramiro de Maetzu, 14, 46900 . \\ Torrente, Valencia, España. \\ juanjose.rabade@mail.ucv.es
}

\begin{abstract}
Introduction: Several studies have analyzed the relationship between physical activity and bone density. However, the prescription of exercise is not entirely clear as to the type, quantity and intensity. Objective: The objective of this study was to determine if there is a relationship between the amount of exercise and changes in bone mineral density. Methods: Fifty-two women, members of the Municipal Program of Physical Activity for Seniors, voluntarily underwent two ultrasonographies of the calcaneus within a 6-month interval. During this period, all physical activity was recorded. Afterwards, a lineal correlation study was carried out between the amount of exercise and bone changes, expressed as T-Score variation, first in total number of participants and then in groups. Considering the average body weight obtained for all women, two groups were created ("light" $<69 \mathrm{~kg}$ and "heavy" $>69 \mathrm{~kg}$ ). Later, women who had participated in less than $72 \%$ of the targeted program were excluded from both groups, and the differences between the groups "light and trained" and "heavy and trained" were analyzed. To do so, the nonparametric Mann-Whitney $U$ test was used. Results: A significant relationship of $r=-0.59$ was found between the total amount of exercise and the T-Score variation in the group of women above $69 \mathrm{~kg}$. Significant differences were found between the "light and trained" group and the "heavy and trained" group with respect to the variation of T-Score. Conclusion: The effect of exercise on bone mineral density is determined, somehow, by body weight. This interaction is due, possibly, to mechanical demands difference.
\end{abstract}

Keywords: exercise; bone and bones; osteoporosis; aged; body weight.

\section{RESUMO}

Introdução: Vários estudos analisaram a relação à quantidade de atividade física e densidade óssea. No entanto, a prescrição de exercício físico não é totalmente clara, em relação ao tipo, quantidade e intensidade. Objetivos: 0 objetivo deste estudo foi determinar se existe relação entre a quantidade de exercício físico e alterações na densidade óssea. Métodos: 52 mulheres, membros do programa municipal de atividade física para idosos participaram voluntariamente na realização de dois ultrassonografias de calcâneo, separado 6 meses. Durante este período, toda a atividade física foi registrada. Em seguida, foi realizado um estudo de correlação linear entre a quantidade de exercício físico e alterações ósseas, expressos como variação do T-Score, primeiro de maneira conjunta e despois em grupos. Considerando-se o peso corporal médio obtido para todas as mulheres, dois grupos foram criados ("magro" $<69 \mathrm{Kg}$ e"pesado" > 69 Kg). Mais tarde, as mulheres que tinham participado em menos do $72 \%$ do programa alvejado foram excluídas de ambos os grupos, e foram analisadas as diferenças entre o grupo "magro e treinado" e o grupo "pesado e treinado". Para alcançar este objetivo, foi utilizado o teste não paramétrico da U de Mann-Whitney. Resultados: foi encontrada ama relação significativa de $r=-0,59$ entre a quantidade total do exercício físico e da variação do T-Score, no grupo das mulheres de mais do que $69 \mathrm{Kg}$. Foram encontradas diferenças significativas entre o grupo "magro y treinado" e o grupo "pesado e treinado", em relação à variação do T-Score. Conclusão: o efeito do exercício físico na densidade mineral óssea é determinado de alguma forma, pelo peso corporal. Esta interação é possivelmente devida à diferente demanda mecânica.

Descritores: exercício, osso e ossos, osteoporose, idosos, peso corporal.

\section{RESUMEN}

Introducción: Diversos estudios han analizado la relación entre la actividad fisica y la densidad ósea. Sin embargo, la prescripción de ejercicio físico no está completamente clara en relación al tipo, cantidad e intensidad. Objetivo: El objetivo de este estudio fue determinar si existe relación entre la cantidad de ejercicio y los cambios en la densidad mineral ósea. Métodos: Cincuenta y dos mujeres, integrantes del Programa Municipal de Actividad Física para Mayores, participaron voluntariamente en la realización de dos ultrasonografías de calcáneo, con intervalo de 6 meses. Durante este periodo, se registró toda la actividad física. A continuación, se realizó un estudio de correlación lineal entre la cantidad de ejercicio y cambios óseos, expresados como la variación del T-Score, primero de forma conjunta y posteriormente por grupos. Teniendo en cuenta el peso corporal medio obtenido para el total de mujeres, 
se crearon dos grupos ("ligero" < $69 \mathrm{Kg}$ y "pesado" > $69 \mathrm{Kg}$ ). Más tarde, las mujeres que habían participado en menos del $72 \%$ del programa dirigido fueron excluidas de ambos grupos y se analizaron las diferencias entre el grupo "ligero y entrenado" y el grupo "pesado y entrenado". Para lograr este objetivo, se utilizó la prueba no paramétrica de la U de Mann-Whitney. Resultados: Se encontró una relación significativa de $r=-0,59$ entre la cantidad total de ejercicio físico y la variación del T-Score en el grupo de mujeres de más de $69 \mathrm{Kg}$. Se encontraron diferencias significativas entre el grupo "ligero y entrenado" y el grupo "pesado y entrenado" con respecto a la variación del T-Score. Conclusión: El efecto del ejercicio físico sobre la densidad mineral ósea está determinado, de alguna manera, por el peso corporal. Esta interacción es debida posiblemente a la diferente demanda mecánica.

Descriptores: ejercicio; huesos, osteoporosis; anciano; peso corporal.

\section{INTRODUCTION}

Osteoporosis is a metabolic disease that causes a bone tissue microarchitecture alteration. It is also characterized by low bone density, thus increasing bone fragility and the risk of fracture ${ }^{1-3}$. It affects 22 million women and 5.5 million men throughout Europe ${ }^{4}$.

Fractures due to bone fragility generate negative outcomes on the individual and its closer environment, as well as high expenses for health assistance systems ${ }^{5}$. Besides, osteoporosis prevalence is possibly underrated on account of its silent course along most of its development. This acquires a higher relevance as, according to demographic predictions, by the year 2050, 19\% of world's population will be over 65 years old. This growth will keep Europe at the top of world's ratings, with $28 \%$ of its population, above this age ${ }^{6}$. If this progressive aging takes place, osteoporosis prevalence will increase ${ }^{7}$ and along with it, personal and economical expenses. Actually, within Europe, the economical expense of osteoporosis is projected to increase as high as 25\% by $2025^{4}$.

For this reason, it is crucial to develop effective strategies in order to decrease osteoporosis incidence in population. In this sense, one of the operation fields focuses on physical exercise programs design aiming to stop bone mineral density decreasing in post-menopausal women. Nevertheless, despite having proved sedentary lifestyle or prolonged immobilization to favour bone mass loss ${ }^{8}$, prescription of physical exercise is not completely clear, with regard to its type, amount and intensity 9 . That is because the optimum stimulus that triggers bone adaptation mechanism is not precisely known ${ }^{10}$. In fact, several authors concur claiming that the most advisable type of exercise for a person suffering from osteoporosis or osteopenia cannot be precisely determined ${ }^{11-13}$. Several articles have analysed the relation among physical activity and bone density, however, few studies have analyzed the effect of different amounts of physical activity on bone density ${ }^{9,13}$. Regarding this issue, one paper $^{14}$, showing up the need of knowing how the amount of weekly training sessions affects bone density, must be highlighted.

Accordingly, the objective of this study is to analyze if there is any relationship between the amount of physical exercise and bone mineral density response, in older women, and if this relationship is determined by body weight.

\section{METHODS}

This study has the ethical institutional approval (Autonomic Ethics Committee of Clinical Trials with Medicines and Medical Devices of Valencian Community) and it has been developed following the ethical principles defined in the Declaration of Helsinki (DoH) made by the World Medical Association in 2013, as well as the regulations on good clinical practices recommended by the Spanish Agency of Medicines and Medical Devices. Written consent was obtained.

Firstly, in order to ensure a wide enough sample of active women, members of the Physical Activity and Health Program for Seniors su- pported by Torrente Hall voluntarily participated. Initially 82 women consented to their participation in this study.

Two evaluations of bone mineral density using calcaneal quantitative ultrasound were performed. For their realization, Sonost 2000, that quantifies ultrasound wave modifications when it goes through the bone ${ }^{15}$ was used. That is, BUA (Broadhand Ultrasound Attenuation, $\mathrm{dB} / \mathrm{MHz}$ ) and SOS (Speed of Sound, $\mathrm{m} / \mathrm{s}$ ). From these two parameters, bone mineral density is estimated and T-Score is calculated. Changes in bone mineral density were expressed with T-score variation. This is a non-invasive method without radiation (precision error lower than 1.5\%), that can be used to assess changes in bone health induced by workout ${ }^{16}$. A 6-month period was settled between measurements, since after the fourth month significant changes can be observed in bone variables ${ }^{17}$.

All measures were carried out at the Catholic University of Valencia Sport Sciences Laboratory, without moving the instruments and with similar temperature and humidity conditions. In all cases the non-dominant foot was chosen to perform the ultrasonography test. Besides, the intervention was completed by incorporating an anthropometric study by electrical bioimpedance. A Tanita BC 418 MA weighing scale was used for this purpose, with a $0.1 \%$ precision.

Features of Physical Activity and Health Program for seniors were analyzed during these six months. In order to carry this out, attendance to guided sessions and performed exercises, including the amount of series and repetitions, were registered. Along with the guided training program, extra physical activity was also controlled through a training diary. The training volume was defined as the amount of exercise. It was expressed in terms of attendance to program (\%), extra physical activity (minutes) and total activity (minutes).

Once both calcaneal ultrasonographies were performed and physical exercise was registered, data statistical treatment began aided by SPSS Statistics 22.0, fixing a signification level of $p=0.05$. The statistical power was calculated with the $G^{*}$ Power 3.1.9.2. In the first place, a descriptive survey (mean \pm standard deviation) of anthropometric characteristics and initial bone status (T-Score) was performed and the training program (guided sessions amount, walking time and total exercise time) was also analyzed. Moreover, information about lifestyle relating to alcohol and tobacco consumption, solar exposition and ingested food products, was collected through questionnaires. Furthermore, medicines taken by each woman were registered, to make sure that none of them was following any kind of hormone therapy. Based on data collected, a lineal correlation study was carried out between the amount of physical exercise performed and changes experienced in bone mineral density, expressed as T-Score variation.

Two groups were created based on baseline descriptive data related to mean body weight for all women. The "Light" group (< $69 \mathrm{~kg}$ ) and the "Heavy" group (> 69kg). In each of the groups, a lineal correlation study was performed between the amount of training and changes in bone mineral density. 
Afterwards, women having participated in less than $72 \%$ of guided training were excluded from both groups. This cut off point was established considering the mean of attendance to guided training sessions. Thus, two new groups were obtained, "Light and Trained" group and "Heavy and Trained" group. From these groups, the effect of the same amount of physical exercise over T-Score variation was analyzed, in women with different weight. To do so, independent samples Mann-Whitney U non-parametric test was used.

\section{RESULTS}

Among the eighty-two women initially registered in the Municipal Physical Activity Program for Seniors, only 52 participated in every measurement. Descriptive study results (mean \pm standard deviation) are shown in Table 1 for all women $(n=52)$. In addition to initial bone status and anthropometric features, lifestyle was also analyzed. Results showed low or inexistent consumption of alcohol and tobacco. However, although the nutritional study was limited to observe non ingested food groups, a common tendency to eat a few quantity and in an unbalanced way was observed. Conversely, solar exposition was considered satisfactory, reaching approximately 30 minutes a day. Besides, none of the women followed any kind of hormone therapy during the term of study.

Regarding the training program, it took place over six months, with two 60 minute weekly sessions. Sessions were carried out non-consecutively, with a rest day in between. The mean follow-up of the program was $72 \%$. Concerning the guided training load, activities oriented to leg exercising were organized in 2-3 series of 20-30 repetitions, adding up 8-9 exercises per session. $1 / 2$ squats over 30 repetitions, splits or strides, ankle extensions and step climbing were the most common exercises. Equilibrium and shifting exercises over 100 repetitions per series were also performed. This means high volume and low intensity, because all exercises were executed only with the body weight or with small overloads like medicine balls of $1-3 \mathrm{~kg}$. In addition to guided training program, extra physical exercise was also registered. The most common activity was walking, with a monthly mean of 342 (236) minutes. This implies around an hour and a half a week.

Lineal correlation study, for the whole set of women, did not reveal significant relationships between the amount of physical exercise and bone mineral density changes, expressed as T-Score variation. Inside each group a lineal correlation analysis was again performed. "Heavy" group obtained a significant relationship $(p=0.03)$ of $r=-0.46$ between guided sessions percentage and T-Score variation. In that sense, it was found as well that walking time correlated significantly ( $r=-0.43$ and $p=0.047)$ with T-Score variation. The relationship found between the total amount of exercise and T-Score changes was a bit higher $(r=-0.59$ and $p=0.004)$. This shows that, the higher the training load, the higher the bone mass loss in women over $69 \mathrm{Kg}$, because inverse relationship is established over a negative sign variable. However, in the "Light" group, no relationship between training volume and T-Score changes was found.

The analysis of differences between "Light and Trained" group $(n=20)$ and "Heavy and Trained" group ( $n=13)$ was carried out through a Mann-Whitney $U$ non-parametric test, obtaining as a result that there are statistically significant differences in T-Score variation among groups $(p=0.014)$. This test had an effect size of 0.9 . The statistical power (one-tailed) was 0.8. Figure 1 shows the T-Score variation for each group and as the same load of training (more than $72 \%$ of guided sessions) produces distinct effects depending on body weight. The performed training program proved to be more positive for the "Light and Trained" group women.
Table 1. Sample characteristics before carrying out the training program. Mean and standard desviation (SD)

\begin{tabular}{c|c|c|c|c|c|c|c|c|c}
\hline \multicolumn{2}{c|}{$\begin{array}{c}\text { Age } \\
\text { (Years) }\end{array}$} & \multicolumn{2}{c|}{$\begin{array}{c}\text { Weight } \\
\text { (Kg) }\end{array}$} & \multicolumn{2}{c|}{$\begin{array}{c}\text { Height } \\
(\mathbf{c m})\end{array}$} & \multicolumn{2}{c|}{$\begin{array}{c}\text { Body Mass } \\
\text { Index (Kg/m²) }\end{array}$} & \multicolumn{2}{c}{$T$-Score } \\
\hline Mean & SD & Mean & SD & Mean & SD & Mean & SD & Mean & SD \\
\hline 72.2 & $(4.7)$ & 68.9 & $(11.3)$ & 155.1 & $(6.1)$ & 28.7 & $(4.7)$ & -1.8 & $(0.7)$ \\
\hline
\end{tabular}

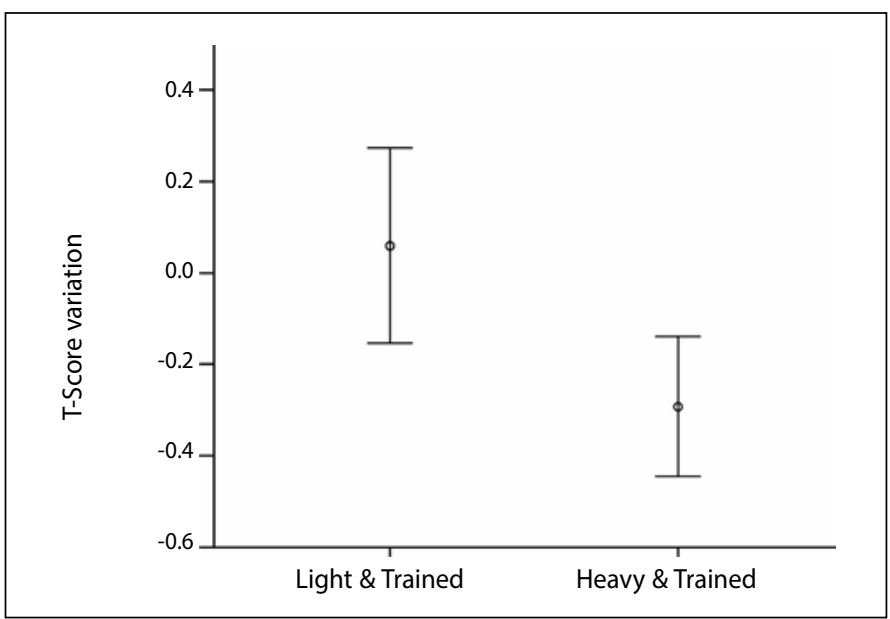

Figure 1. T-Scc variation by weight groups (mean and confidence interval at 95\%).

\section{DISCUSSION}

Several papers ${ }^{18-20}$ have analysed bone mineral density response to physical exercise in older women, but the results are conflicting, depending of the anatomical measurement region. However, for our knowledge, few tried to establish some kind of relationship between the amount of training and modifications achieved in bone mass $s^{9,13}$. One of these papers ${ }^{13}$ analyzed bone response to different frequencies of the same force with overloads training program. More precisely, effects of a single session per week were compared with two sessions per week, showing that none of both frequencies carried significant changes in bone density concerning external without overload toning exercises group. These results are consistent with those obtained in our work, because for all women $(n=52)$ no relationship between amount of exercise and T-Score changes was found. These data could indicate that more exercise performance does not guarantee achieving a positive adaptation. Nonetheless, some papers ${ }^{9,21}$ show that an increase of daily physical activity can prevent post-menopausal bone loss. These results suggest the possibility that other factors determine bone response to physical exercise. For this reason, two groups of women were created taking as a reference mean body weight. "Light" group ( $<69 \mathrm{Kg}, \mathrm{n}=30$ ) and "Heavy" group (>69Kg, n=22). Finally, all women participating in less than $72 \%$ of guided training sessions were excluded from both groups. According to this criterion two new groups were created.

Conversely, a higher weekly frequency ${ }^{22}$ does not guarantee significant changes in bone mass. In fact, in this paper above, the group of women having performed three training sessions a week (3 exercises with 3 series of 10-12 repetitions at 60\%-70\% 1RM), during six months, did not modify their bone density. These results are similar to those obtained for the "Light and Trained" group, despite having used in our work a different training load (higher volume and lower intensity). However, the loss experienced by the "Heavy and Trained" group suggests that women with higher body weight need a different training load. Indeed, it is possible that the effect caused by exercise over bone tissue is determined, up to some point, by individual factors. Among these ones, body weight can play a basic role, because it modifies mechanical 
demand over the bone induced by exercise. This is important when the training program design is based on strength exercises without external overloads.

Concerning training volume, if the results achieved with exercise programs developed with a higher amount of weekly sessions are analyzed, no higher benefits are obtained. In fact, results are a bit diverse. Some papers ${ }^{23}$ found a significant fall in bone mass, with four sessions per week. However, a five sessions per week program ${ }^{24}$ led to a remarkable density increase, about $4 \%$, compared to the initial level. Nevertheless, women around $45 \mathrm{~kg}$ participated in this program, performing 15 repetition series, while in our study 30 repetitions per series were done, concentrated in two weekly sessions.

On account of such a sparse bibliography related to physical exercise amount and changes in bone density, no relationship can be established between training load and bone response, because program intensity and structure regarding exercise amount, series and repetitions, determine effects on bones. Even speed of execution can be a relevant element when controlling bone adaptation ${ }^{11}$.

Mechanical demand is an essential element in bone adaptation, as pointed out in papers with prolonged exposure to microgravity ${ }^{25}$. However, it is not known in detail the necessary load to achieve a favourable bone adaptation. In any case, a maximum threshold must exist in terms of physical exercise amount. In fact, some papers ${ }^{26}$ show that highest bone density levels are seen in active women, while female athletes, although having slightly higher values than those of sedentary lifestyle women, did not significantly differ from these ones. However, it also seems necessary to reach a minimum threshold to start up bone adaptation mechanisms. Thus, active women performing physical exercise systematically show better ultrasonography parameters than the sedentary lifestyle or moderately active ones ${ }^{27}$.

\section{CONCLUSION}

This paper represents one of the first attempts to clear up the relationship between physical exercise amount and bone tissue response. But, this relationship may be determined by individual factors as, for instance, body mass. In this sense, a higher body weight implies a mechanical load increase that musculoskeletal system has to cope with, especially the skeleton, while physical exercise is being carried out. This higher demand could exceed organism adaptive capacity, preventing from positive results achievement for bone health. In any case, we think that there is an optimal training load zone according to individual characteristics, which could develop effective strategies to face osteoporosis. Therefore, in the field of physical exercise, bone health improvement strategies must take personal characteristics into account, especially concerning body weight.

All authors have declared there is not any potential conflict of interests concerning this article.

CONTRIBUIÇÕES DOS AUTORES: Cada autor contribuiu individual e significativamente para o desenvolvimento do manuscrito. JJRE (0000-0001-9938-0178)* e TVE (0000-0002-8712-9872)* foram os principais contribuintes na redação do manuscrito. JJRE, TVE e APM (0000-0002-1915-9906)* reuniram dados clínicos. CPA (00000002-5567-2037)* e VCD (0000-0002-6597-8419)* avaliaram os dados da análise estatística e projeto de estudo. JJR, TVE realizaram a pesquisa bibliográfica. JJRE, TVE, APM (0000-0002-1915-9906)*, CPA (0000-0002-5567-2037)* e VCD realizaram a revisão do manuscrito e contribuíram com o conceito intelectual do estudo. Todos os autores têm contribuído ativamente da discussão dos resultados e na revisão e aprovação da versão final do trabalho. *Número ORCID (Open Research and Contributor ID).

\section{REFERENCES}

1. Borer KT. Physical activity in the prevention and amelioration of osteoporosis in women: interaction of mechanical, hormonal and dietary factors. Sports Med. 2005;35(9):779-830.

2. Howe TE, Shea B, Dawson LJ, Downie F, Murray A, Ross C, et al. Ejercicios para la prevención y el tratamiento de la osteoporosis en mujeres posmenopáusicas. Rev Med Clín Condes. 2013;24(5):876-7.

3. Lane NE. Epidemiology, etiology, and diagnosis of osteoporosis. Am J Obstet Gynecol. 2006;194(2 Suppl):S3-11.

4. Hernlund E, Svedbom A, Ivergård M, Compston J, Cooper C, Stenmark J, et al. Osteoporosis in the European Union: medical management, epidemiology and economic burden. A report prepared in collaboration with the International Osteoporosis Foundation (IOF) and the European Federation of Pharmaceutical Industry Associations (EFPIA). Arch Osteoporos. 2013;8:136.

5. Del Pino J. Coste de la osteoporosis postmenopáusica. Rev Osteoporos Metab Miner. 2012;4(Suppl. 1):17-21.

6. LutzW, KC S. Dimensions of global population projections: what do we know about future population trends and structures? Philos Trans R Soc Lond B Biol Sci. 2010;365(1554):2779-91.

7. Hadji P, Klein S, Gothe H, Häussler B, Kless T, Schmidt T, et al. The epidemiology of osteoporosis--Bone Evaluation Study (BEST): an analysis of routine health insurance data. Dtsch Arztebl Int. 2013;110(4):52-7.

8. Armbrecht G, Belavý DL, Backström M, Beller G, Alexandre C, Rizzoli R, et al. Trabecular and cortical bone density and architecture in women after 60 days of bed rest using high-resolution PQCT: WISE 2005. J Bone Miner Res. 2011;26(10):2399-410.

9. Muir JM, Ye C, Bhandari M, Adachi JD, Thabane L. The effect of regular physical activity on bone mineral density in post-menopausal women aged 75 and over: a retrospective analysis from the Canadian multicentre osteoporosis study. BMC Musculoskelet Disord. 2013;14:253.

10. Kohrt WM, Villalon KL, Barry DW. Effects of exercise and physical interventions on bone: Clinical studies. Stud Mechanobiol Tissue Eng Biomater. 2013;5:235-56.

11. Stengel SV, Kemmler W, Pintag R, Beeskow C, Weineck J, Lauber D, et al. Power training is more effective than strength training for maintaining bone mineral density in postmenopausal women. J Appl Physiol (1985). 2005;99(1):181-8.

12. Ferragut C, Torres-Luque, G, Alacid-Cárceles F, Sainz de Baranda P. Masa ósea y ejercicio físico. Arch Med Deporte.. 2009;129:46-60.

13. Ashe MC, Gorman E, Khan KM, Brasher PM, Cooper DM, McKay HA, et al. Does frequency of resistance training affect tibial cortical bone density in older women? A randomized controlled trial. Osteoporos Int. 2013;24(2):623-32

14. Kemmler W, von Stengel S. Dose-response effect of exercise frequency on bone mineral density in post-menopausal, osteopenic women. Scand J Med Sci Sports.2014;24(3):526-34.

15. Gómez C, Díaz JB. Métodos de determinación de la densidad mineral ósea. Rev Clin Esp (Barc). 2009;209(Suppl 1):15-22.

16. Babatunde OO, Forsyth JJ. Quantitative Ultrasound and bone's response to exercise: a meta analysis, Bone. 2013;53(1):311-8.

17. Gómez-Cabello A, Ara I, González-Agüero A, Casajús JA, Vicente-Rodríguez G. Effects of training on bone mass in older adults: a systematic review. Sports Med. 2012;42(4):301-25.

18. Holm L, Olesen JL, Matsumoto K, Doi T, Mizuno M, Alsted TJ, et al. Protein-containing nutrient supplementation following strength training enhances the effect on muscle mass, strength, and bone formation in postmenopausal women. J Appl Physiol (1985). 2008;105(1):274-81.

19. Maddalozzo GF, Widrick JJ, Cardinal BJ, Winters-Stone KM, Hoffman MA, Snow CM. The effects of hormone replacement therapy and resistance training on spine bone mineral density in early postmenopausal women. Bone. 2007;40(5):1244-51.

20. Verschueren SM, Roelants M, Delecluse C, Swinnen S, Vanderschueren D, Boonen S. Effect of 6-month whole body vibration training on hip density, muscle strength, and postural control in postmenopausal women: a randomized controlled pilot study. J Bone Miner Res. 2004;19(3):352-9.

21. Kemmler W, von Stengel S. Exercise frequency, health risk factors, and diseases of the elderly. Arch Phys Med Rehabil. 2013;94(11):2046-53.

22. Bocalini DS, Serra AJ, Dos Santos L. Moderate resistive training maintains bone mineral density and improves functional fitness in postmenopausal women. J Aging Res. 2010;2010:760818.

23. Kemmler W, Lauber D, Weineck J, Hensen J, Kalender W, Engelke K. Benefits of 2 years of intense exercise on bone density, physical fitness, and blood lipids in early postmenopausal osteopenic women: results of the Erlangen Fitness Osteoporosis Prevention Study (EFOPS). Arch Intern Med. 2004;164(10):1084-91.

24. Iwamoto J, Takeda T, Ichimura S. Effect of exercise training and detraining on bone mineral density in postmenopausal women with osteoporosis. J Orthop Sci. 2001;6(2):128-32.

25. Orwoll ES, Adler RA, Amin S, Binkley N, Lewiecki EM, Petak SM, et al. Skeletal health in long-duration astronauts: nature, assessment, and management recommendations from the NASA Bone Summit. J Bone Miner Res. 2013;28(6):1243-55.

26. Hagberg JM, Zmuda JM, McCole SD, Rodgers KS, Ferrell RE, Wilund KR, et al. Moderate physical activity is associated with higher bone mineral density in postmenopausal women. J Am Geriatr Soc. 2001:49(11):1411-7.

27. Dionyssiotis Y, Paspati I, Trovas G, Galanos A, Lyritis GP. Association of physical exercise and calcium intake with bone mass measured by quantitative ultrasound. BMC Womens Health. 2010;10:12. 